\title{
COVID-19 ENFEKSIYONU ILE KOMPLIKE GEBE HASTALARDA MATERNAL VE NEONATAL SONUÇLARIN DEĞERLENDIRILMESI
}

\author{
EVALUATION OF MATERNAL AND NEONATAL OUTCOMES IN PREGNANT \\ PATIENTS COMPLICATED BY COVID-19 INFECTION
}

\author{
Ümran KILINÇDEMIR TURGUT ${ }^{1}$, Gökhan BAYHAN ${ }^{1}$ \\ ${ }^{1}$ Süleyman Demirel Üniversitesi Kadın Hastalıkları ve Doğum Ana Bilim Dalı, Isparta, Türkiye
}

Cite this article as: Kılınçdemir Turgut Ü, Bayhan G. Evaluation of Maternal and Neonatal Outcomes in Pregnant Patients Complicated by COVID-19 Infection. Med J SDU 2021; (ozelsayi-1):119-124.

\section{Öz}

Mevcut derlemenin amacı, gebelik sırasında maternal Coronavirus Disease 2019 (COVID-19) enfeksiyonunun anne sağlığı üzerine etkilerinin belirlenmesi ve neonatal sonuçlar üzerine etkisinin analiz edilmesidir. Bu çalışmada, 1 Şubat 2020- 1 Mart 2021 tarihleri arasında yayınlanmış makalelerin, Pubmed ve Google Scholar üzerinden kapsamlı bir literatür taraması yapılmıştır. Anahtar kelimeler 'COVID-19, SARS-CoV-2, pregnancy, maternal complications, fetal complications, maternal mortality, fetal mortality' şeklinde olup İngilizce dil kısıtlaması yapılmıştır. Bu kriterlere uygun 8 çalışma dahil edilmiştir. Toplam 724 nazal sürüntü örneğinde polimeraz zincir reaksiyonu (PCR) ile COVID-19 enfeksiyonu doğrulanmış gebe hasta ve kontrol grubu olarak nazal sürüntü örneğinde COVID-19 PCR ile enfeksiyon olmadığı kanıtlanmış olan 6001 gebe dahil edilmiştir. Analiz edilen değişkenler; maternal yaş, eşlik eden komorbidite durumu, COVID-19 hastalık semptomları, pnömoni varlığı, maternal yoğun bakım intiyacı, maternal mortalite, abortus varlığı, preterm doğum oranı, doğum şekli, yenidoğan yoğun bakım intiyacı, yenidoğan COVID-19 PCR durumu ve COVID-19'a bağlı yenidoğan mortalite oranıdır. Maternal COVID-19 enfeksiyonu vakalarının \%50'sinde asemptomatik seyretmiştir. Klinik semptomlar \%39 ile öksürük, \%34 ateş, \%24 koku kaybı, \%16 dispne şek- lindedir. Maternal enfeksiyonda hastaların \%13'ünde hastanede yatış gerekliliği belirlenmiştir. Akciğer tutulumu \%14 olup, hastaların \%2'si yoğun bakım şartlarında tedavi edilmiștir. Maternal mortalite $\% 0,7$ olarak saptanmıştır. Maternal ve neonatal sonuçlar için yenidoğan yoğun bakım intiyacı oranı dışında anlamlı fark saptanmadı. Yenidoğan COVID-19 PCR taramasında \%2 pozitiflik saptanmasına rağmen COVID-19 enfeksiyonuna bağlı yenidoğan ölümü saptanmadı. COVID-19 enfeksiyonu ile komplike gebe hastalarda, maternal ve neonatal sonuçlarda kötüleșme saptanmadı. Anneden bebeğe vertikal geçiş gösterilmemekle beraber $\% 2$ yenidoğan PCR ile pozitiflik oranı bildirilmiştir. Hastaneye kabulde tüm gebelerin taranması önem taşıyabilir.

Anahtar Kelimeler: COVID-19, SARS-CoV-2, maternal enfeksiyonlar, maternal komplikasyonlar, fetal komplikasyonlar.

\section{Abstract}

The purpose of this review is to determine the effects of maternal Coronavirus Disease 2019 (COVID-19) infection during pregnancy on maternal health and evaluating its effect on neonatal outcomes. In this study, a comprehensive literature review was carried out on Pubmed and Google Scholar for articles published between February 1, 2020 and March 1, 2021. The 
keywords were 'COVID-19, SARS-CoV-2, pregnancy, maternal complications, fetal complications, maternal mortality, fetal mortality' and English language restriction has been applied. Eight studies were included. Pregnant patients with confirmed COVID-19 infection by polymerase chain reaction (PCR) in a total of 724 nasal swab samples and 6001 pregnant women, who were proven to be free of infection by COVID-19 PCR in the nasal swab sample were included as a control group. The variables analyzed were maternal age, comorbidity status, symptoms of COVID-19 disease, presence of pneumonia, maternal intensive care need, maternal mortality, presence of abortion, preterm delivery rate, delivery type, neonatal intensive care need, neonatal COVID-19 PCR status, and neonatal mortality rate due to COVID-19. Maternal COVID-19 infection was asymptomatic in $50 \%$ of the cases. Clinical symptoms were 39\% cough, 34\% fever, 24\% loss of smell, and $16 \%$ dyspnea. The requirement for hospitalization was determined in $13 \%$ of the patients in maternal infection. Lung involvement was $14 \%$, and $2 \%$ of the patients have been treated in intensive care conditions. Maternal mortality was found to be $0.7 \%$. No significant difference was found for maternal and neonatal outcomes, except for the rate of neonatal intensive care need $(p=0,03)$. Although $2 \%$ positivity was detected in the neonates, there were no neonatal deaths due to COVID-19. Maternal and neonatal outcomes were similar to controls in pregnant patients complicated by COVID-19 infection. Although vertical transmission was not shown, a neonatal positivity rate of $2 \%$ has been reported. Screening of all pregnant women at hospital admission may be crucial

Keywords: COVID-19, SARS-CoV-2, maternal infections, maternal complications, fetal complications.

\section{Giriş}

Yeni coronavirus ilk defa Aralık 2019'da Çin-Wuhan kentinde tanımlanmıştır. COVID-19 veya SARSCoV-2 olarak isimlendirilen bu yeni coronavirüs bir RNA virüsü olup, Severe Acute Respiratory Syndrome (SARS) ve Middle East Respiratory Syndrome (MERS) ile benzerlikleri dikkati çekmiştir.

Gebelikte SARS ve MERS enfeksiyonlarının ciddi gebelik komplikasyonlarını artırabileceği ile ilgili bulgular, SARS-CoV-2 enfeksiyonu içinde gebelikte mortalite ve morbiditeyi artırabileceği yönünde endişeleri artırmıştır (1)(2).

Çalışmanın amacı gebelik sırasında maternal Coronavirus Disease 2019 (COVID-19) enfeksiyonunun anne sağlığı üzerine etkilerinin belirlenmesi ve neonatal sonuçlar üzerine etkisinin değerlendirilmesidir.

\section{Gereç ve Yöntem}

Pubmed ve Google Scholar veri tabanları üzerinden 1 Şubat 2020 - 1 Mart 2021 tarihleri kapsamlı bir literatür taraması yapıldı. Anahtar kelimeler 'COVID-19, SARS-CoV 2, pregnancy, maternal complications, fetal complications, maternal mortality, fetal mortality" olarak kullanılmışı ır. Ingilizce dil kısıtlaması kullanılmıştır. Bu kriterlere uygun 8 çalışma dahil edilmiştir (Tablo.1). Toplam 724 nazal sürüntü örneğinde PCR ile COVID-19 enfeksiyonu doğrulanmış gebe hasta ve kontrol grubu olarak nazal sürüntü örneğinde CO-
VID-19 PCR testleri negatif olan 6001 gebe dahil edilmiştir. Analiz edilen değişkenler; maternal yaş, eşlik eden komorbidite durumu, COVID-19 hastalık semptomları, pnömoni varlığı, yoğun bakım intiyacı, maternal mortalite, abortus varlığı, preterm doğum oranı, doğum şekli, yenidoğan yoğun bakım intiyacı, yenidoğan COVID-19 PCR durumu, COVID-19 'a bağlı yenidoğan mortalite oranı şeklindedir.

İstatistiksel analizde sonuçlar için frekans ve sıklık hesaplaması yapıldı. Gruplar arası değerler ki-Kare testi kullanılarak karşılaştırıldı. Yüzde 95 güven aralığında p değeri $<0,05$ anlamlı kabul edildi. Gruplar karşılaştırılarak \%95 güven aralığında olasılık oranları hesaplandı.

\section{Bulgular}

Çalışmamızda, COVID-19 ile enfekte gebe hasta grubunda maternal yaș 17 ile 47 arasında değișmekte olup ortalama yaklaşık olarak 31 olarak belirlendi. Eşlik eden komorbidite durumu (hipertansiyon, diyabet, astım, kronik akciğer hastalığı, obezite) \%23 olarak saptandı. Maternal yaş ve komorbidite durumu, kontrol grubu ile karşılaştırıldığında istatistiksel olarak benzerdi.

Klinik bulgu ve semptomlar; COVID- 19 enfeksiyonu tanısı PCR ile kesinleşen gebe hastaların \%50'sinde herhangi bir klinik semptom veya bulguya rastlanmamış olup asemptomatiktir. En sık semptom \%39 ile öksürüktür. Diğer semptomlar sırasıyla \%34 ateş, \%24 koku kaybı, \%16 dispne şeklindedir. 
COVID-19 enfeksiyonu ile komplike gebe hastalarda \%13 hastanede yatış gerekliliği belirlendi. Akciğer tutulumu \%14 olup, hastaların \%2'si yoğun bakım şartlarında tedavi edilmiştir. Maternal mortalite $\% 0,7$ olarak saptanmıştır.

Maternal sonuçlar; COVID-19 enfeksiyonu ile komplike gebe hastalarla, benzer yaş grubu COVID-19 hastalık bulgusu olmayan veya PCR ile enfeksiyon olmadığı doğrulanmış gebe kadınlar karşılaştırıldı. Ek komorbidite hastalık varlığı gruplar arasında benzerdi. Maternal mortalite, abortus, postpartum kanama, doğum şekilleri, preterm doğum oranları, yenidoğan yoğun bakım ihtiyacı olan yenidoğan oranı belirlendi. Gruplar arasında istatistiksel olarak maternal ve neonatal sonuçlar için yenidoğan yoğun bakım ihtiyacı dışında anlamlı fark saptanmadı. Yenidoğan yoğun bakım ihtiyacı ise COVID-19 enfeksiyonu ile komplike olmayan kontrol grubunda istatistiksel olarak anlamlı daha yüksek oran belirlenmiştir. Bu durum derlemeye dahil edilen çalışmaların heterojenitesinden kaynaklanmış olabilir. Yenidoğan COVID-19 PCR taramasında \%2 pozitiflik saptanmasına rağmen, takip eden günlerde PCR tekrarı negatif olup, yenidoğan bebeklerin hiçbirinde enfeksiyon bulgularına rastlanılmadı. COVID-19 enfeksiyonuna bağlı yenidoğan ölümü saptanmadı.

\section{Tartışma}

\section{Covid-19 Enfeksiyonunda Maternal Bulgu Ve Semptomlar}

COVID-19 enfeksiyonu ateş, öksürük, nefes darlığı, baş ağrısı, gibi başlıca semptom ve bulguların olduğu bilinmektedir. Fakat enfeksiyona maruz vakaların bir kısmının asemptomatik veya çok hafif semptomlarla hastalığı geçirdiği ortaya konulmuştur. Yapılan bir derlemede COVID-19 enfeksiyonu ile komplike gebeliklerin \%73'ü asemptomatikti ve gebe olmayan benzer yaş kadınlarla kıyaslandığında gebelerde asemptomatik hastalık oranı daha yüksekti (3). Bir başka derlemede ise gebe kadınlarda COVID-19 enfeksiyonu \%59 asemptomatik olarak kalıyordu (4). Mevcut derlemede ise COVID-19 enfeksiyonu ile komplike gebeliklerin \%50'si asemptomatikti. Sonuç olarak, gebelikte COVID-19 enfeksiyonu vakaların önemli bir kısmında herhangi bir semptom ve bulgu vermemektedir. Yeni bir Uptodate taramasında gebe kadınlarda enfeksiyona ait semptom ve bulgular, gebe olmayan benzer yaş grubu kadınlarla karşılaştırılmış ve aşağıdaki bulgular elde edilmiştir (5):

- Öksürük - Gebe yüzde 50,3 (gebe olmayan \% 51,3)

- Baş ağrısı - Gebe yüzde 42,7 (gebe olmayan \% 54,9)

- Kas ağrıları - Gebe yüzde 36,7 (gebe olmayan \% 45,2)

\begin{tabular}{|c|c|c|}
\hline Yazar; yıl & $\begin{array}{l}\text { Hasta gebe sayısı I } \\
\text { toplam gebe }\end{array}$ & Çalışmanın başığı \\
\hline $\begin{array}{l}\text { Crovetto F } \\
2020\end{array}$ & $125 / 874$ & Seroprevalence and presentation of SARS-CoV-2 in pregnancy \\
\hline $\begin{array}{l}\text { Nayak AH } \\
2020\end{array}$ & $141 / 977$ & $\begin{array}{l}\text { Impact of the Coronavirus Infection in Pregnancy: A Preliminary Study } \\
\text { of } 141 \text { Patients }\end{array}$ \\
\hline $\begin{array}{l}\text { Emeruwe U } \\
2020\end{array}$ & $100 / 673$ & $\begin{array}{l}\text { Influence of Race and Ethnicity on Severe Acute Respiratory } \\
\text { Syndrome Coronavirus } 2 \text { (SARS-CoV-2) Infection Rates and Clinical } \\
\text { Outcomes in Pregnancy }\end{array}$ \\
\hline $\begin{array}{l}\text { Sakowicz A } \\
2020\end{array}$ & $101 / 1418$ & $\begin{array}{l}\text { Risk factors for severe acute respiratory syndrome coronavirus } 2 \\
\text { infection in pregnant women }\end{array}$ \\
\hline $\begin{array}{l}\text { Ahlberg M } \\
2020\end{array}$ & $156 / 2682$ & Association of SARS-CoV-2 Test Status and Pregnancy Outcomes \\
\hline Fang L 2020 & $21 / 21$ & $\begin{array}{l}\text { Clinico-Radiological Features and Outcomes in Pregnant Women with } \\
\text { COVID-19 Pneumonia Compared with Age-Matched Non-Pregnant } \\
\text { Women }\end{array}$ \\
\hline Noelle B 2020 & $43 / 43$ & $\begin{array}{l}\text { Coronavirus disease } 2019 \text { infection among asymptomatic and } \\
\text { symptomatic pregnant women: two weeks of confirmed presentations } \\
\text { to an affiliated pair of New York City hospitals }\end{array}$ \\
\hline Panahi L 2020 & $37 / 37$ & $\begin{array}{l}\text { Risks of Novel Coronavirus Disease (COVID-19) in Pregnancy; a } \\
\text { Narrative Review }\end{array}$ \\
\hline
\end{tabular}




\begin{tabular}{|c|c|c|c|c|}
\hline & $\begin{array}{l}\text { Covid-19 pozitif } \\
(n=724)\end{array}$ & $\begin{array}{l}\text { Covid-19 negatif } \\
(n=6001)\end{array}$ & P değeri & $\begin{array}{l}\text { Olasılık oranı (\%95 } \\
\text { güven aralığı) }\end{array}$ \\
\hline Maternal yaş & $31(17-47)$ & $32(18-47)$ & 0,50 & \\
\hline Ek hastalık varlığı & $105 / 440(\% 23)$ & $681 / 2751(\% 28)$ & 0,75 & \\
\hline Asemptomatik & $185 / 369(\% 50)$ & - & & \\
\hline En az bir semptom & $184 / 369(\% 50)$ & - & & \\
\hline Ateş & $22 / 64(\% 34)$ & - & & \\
\hline Koku kaybı & $31 / 125(\% 24)$ & - & & \\
\hline Öksürük & $25 / 64(\% 39)$ & - & & \\
\hline Dispne & 16/189 (\%8) & - & & \\
\hline Hastaneye yatış & $33 / 246(\% 13)$ & - & & \\
\hline Pnömoni & $35 / 246(\% 14)$ & - & & \\
\hline Yoğun bakım ihtiyacı & $3 / 146(\% 2,1)$ & - & & \\
\hline Mortalite & 3/396 (\%0.7) & $8 / 836(0,8)$ & 0,75 & $0,79(0,20-2,95)$ \\
\hline Abortus & $7 / 241(\% 0.2)$ & $33 / 836(\% 0.3)$ & 0,48 & $0,72(0,31-1,66)$ \\
\hline Postpartum kanama & $57 / 394(\% 14)$ & $205 / 1440(\% 14)$ & 0,92 & $0,98(0,71-1,35)$ \\
\hline \multicolumn{5}{|l|}{ Doğum şekli } \\
\hline Vajinal & 239/387 (\%61) & $869 / 1404(\% 61)$ & 0,98 & $0,99(0,78-1,25)$ \\
\hline Sezaryen & 148/387 (\%39) & $535 / 1404(\% 39)$ & 0,97 & $1,0(0,76-1,26)$ \\
\hline $\begin{array}{l}\text { Yenidoğan yoğun bakım } \\
\text { ihtiyacı }\end{array}$ & 25/167 (\%14) & $201 / 816(\% 24)$ & 0,03 & $0,53(0,34-0,84)$ \\
\hline Preterm & 17/183 (\%9) & $45 / 604(\% 7)$ & 0,45 & $1,28(0,70-2,28)$ \\
\hline Yenidoğan PCR pozitifliği & $4 / 162$ & - & & \\
\hline $\begin{array}{l}\text { Covid nedenli yenidoğan } \\
\text { ölümü }\end{array}$ & $0 / 162$ & - & & \\
\hline
\end{tabular}

PCR: polimeraz zincir reaksiyonu

- Ateş - Gebe yüzde 32,0 (gebe olmayan \% 39,3)

- Boğaz ağrısı - Gebe yüzde 28,4 (gebe olmayan \% 34,6)

- Nefes darlığı - Gebe yüzde 25,9 (gebe olmayan \% 24,8)

- Yeni tat veya koku kaybı - Gebe yüzde 21,5 (gebe olmayan \% 24,8)

Sonuçta, gebe kadınlarda COVID-19 enfeksiyonunun gebe olmayan kadınlara oranla daha az semptom ve bulgu ile seyrettiği söylenebilir.

Mevcut derlemede ise en sık bulgu \%39 ile öksürük olup literatür ile uyumludur. Diğer semptomlar sırasıyla \%34 ateş, \%24 koku kaybı ve \%16 dispne şeklindedir.

COVID-19 Enfeksiyonunda Maternal Klinik Seyir Gebelikte COVID-19 enfeksiyonuna bağlı klinik seyir ve mortalite sıklığını saptanmasına ait bir derlemeye göre aşağıdaki komplikaston oranları saptanmıştır (3):

- Yüzde 17.4'ünde pnömoni

- Yüzde 17,1'i kanül ile oksijen desteği

- Yüzde 13,4'ünde akut solunum sıkıntısı sendromu (ARDS)

- Yüzde 3,3'ü bir yoğun bakım ünitesine (YBÜ) yatış intiyacı

- Yüzde 1,6'sı invaziv ventilasyon intiyacı

- Yüzde 0,11 ekstrakorporeal membran oksijenasyonu (ECMO) ihtiyacı

- Yüzde 0,8 maternal mortalite

Derlememizde ise COVID-19 enfeksiyonu ile komplike gebe hastalarda \%13 hastanede yatış gerekliliği belirlendi. Akciğer tutulumu \%14 olup, hastaların \%2'si yoğun bakım şartlarında tedavi edilmiştir. Maternal mortalite \%0,7 olarak saptanmıştır. Saptanan bu oranlar da literatür ile benzerdir. 


\section{COVID-19 ve Gebelik Kaybı}

İlk trimester COVID-19 enfeksiyonu ile düşükler arasında ilişkiyi tanımlayan bir çalışmada, 225 ilk trimester COVID-19 enfeksiyonu ile komplike gebe dahil edilmiş ve erken gebelik kaybı oranı normal popülasyon ile benzer bulunmuştur (6). Benzer şekilde bu çalıșmada COVID-19 enfeksiyonu ile komplike gebe hastalar, enfeksiyonla komplike olmayan gebeler kıyaslandığında erken gebelik kaybı oranı, gruplar arasında benzerdir. Sonuç olarak, yeni coronavirus enfeksiyonu ile düşükler arasında belirgin bir ilişki bulunmamaktadır.

\section{CoVID-19 ve Vertikal Geçiş}

Anneden bebeğe vertikal geçişle ilgili literatürde çaIışmalar mevcut olmakla beraber vertikal geçişe dair net kanıt elde edilememiştir (7). Vertikal geçişi belirlemedeki zorluklar nedeniyle net olarak ortaya koymak mümkün görünmese de çalışmalar yenidoğan nazofaringeal sürüntüde $\mathrm{PCR}$ ile coronavirüs enfeksiyonu saptanan yenidoğanlarda bile prognozun çok iyi olduğu şeklindedir (8). Bu çalışmada yenidoğan nazofaringeal PCR taramasında \%2 pozitiflik saptanmış olmasına rağmen, hiçbirinde hastalık semptomlarına rastlanılmamıştır. COVID-19 enfeksiyonuna bağlı yenidoğan ölümüne rastlanılmamıştır.

\section{Maternal Mortalite}

SARS CoV-1 yüksek maternal mortalite ile ilişki bulunmuş ve \%25 oranı çalışmalarda bildirilmiştir (9). MERS-CoV enfeksiyonu için ise 11 hastayı kapsayan olgu serisinde \%35 maternal mortalite bildirilmiştir (2). Yapılan bir calışmada COVID-19 enfeksiyonu ile komplike olan gebeliklerde maternal mortalite $\% 0,7$ ve risk oranı 2,8 $(1,08-7,52)$ olarak saptanmıştır (3). Bu durumun maternal asemptomatik hastaların tam olarak saptanamamasından kaynaklanmış olabileceği şeklinde yorumlanmıştır. Ayrıca, başka bir çalışmada COVID-19 enfeksiyonuna sahip gebe hastalar ile benzer yaş grubunda hamile olmayan kadınlar karşılaştırılığında benzer mortalite oranları saptanmıştır (3). Mevcut çalışmada ise COVID-19 enfeksiyonu ile komplike gebe hastalarda maternal mortalite $\% 0,7$ olarak saptanmıştır. Kontrol grubu ile karşılaştırıldığında mortalite oranları her iki grup arasında benzer$\operatorname{dir}(p=0,75)$ ve olasılık oranı 0,79 (\%95 güven aralığı: $0,20-2,95)$ olarak belirlenmiştir.

\section{Preterm Doğum}

COVID-19 salgının başlarında düşük sayılı gebe hasta içeren yayınlar, preterm doğum sıklığında artışa dikkat çekmiştir. Otuz yedi gebe hastanın dahil edildiği bir derlemede $\% 47$ preterm doğum oranı saptanmış, doğum endikasyonu olarak ise sıklıkla fetal distres tanımlanmıştır (10). Bir başka derlemede ise
COVID-19 enfeksiyonu ile komplike 237 gebe dahil edilmiş ve preterm doğum oranını \%23 saptanmıştır (11). Yakın zamanda yapılan yüksek gebe hasta sayılarına sahip derlemede ise preterm doğum oranı \%12,4 saptanmış ve 1.5 kat civarında bir risk artışı hesaplanmıştır (3). Mevcut analizimizde ise dahil edilen gebe hastalar içerisinde 183 COVID-19 enfeksiyonu ile komplike gebe hastanın doğum bilgisine ulaşımış ve $\% 9$ preterm doğum oranı saptanmıştır. Kontrol grubu içinde 603 gebenin doğum bilgisine ulaşılarak \%7 preterm doğum oranı bulunmuştur. Bu aşamada COVID-19 enfeksiyonu ile komplike gebe hastalarda, preterm doğum için \%20 oranında belirlenen risk artışının doğruluğunun kanıtlanabilmesi için daha yüksek sayılı hasta popülasyonlarının dahil edildiği çalışmalara intiyaç duyulmaktadır.

\section{Doğum Şekli}

COVID-19 enfeksiyonu ile komplike gebeliklerin yönetiminde belirsizlikler ile birlikte doğum şeklinin belirlenmesi için de çalışmalar literatüre eklenmeye başlamıştır. Ilk bildirilen vakalarda ki yüksek sezaryen oranı dikkati çekmiştir. Yirmi üç COVID-19 enfeksiyonu ile komplike gebe hastanın dahil edildiği dahil edildiği bir çalışmada sezaryen oranı \%60,7 olarak bildirilmiştir (12). Yapılan vaka bildirimlerini içeren diğer bir derlemede ise sezaryen oranı \%90,2 olarak bildirilmiştir (13). Veriler artıkça vajinal doğumun da yeterli korunma önlemleri eşliğinde güvenli olduğu yönünde görüşler artmıştır. Vaka sayısının yüksek olduğu bir derlemede sezaryen oranı \%36,1 olarak bildirilmiştir (3). Mevcut analizde ise sezaryen oranı \%39 olup, doğum şekli kontrol grubu ile karşılaştırıldığında istatistiksel olarak anlamlı fark saptanmamıştır. COVID-19 ile komplike olmuş bir gebe hasta için doğum planlanacak ise obstetrik nedenlere göre doğum şekli belirlenmesi daha uygun olarak görülmektedir.

\section{Neonatal Sonuçlar}

Neonatal sonuçlarla ilgili literatürde çelişkili bilgiler mevcuttur. Bir çalışmada COVID-19 enfeksiyonuna bağlı fetal distres ve preterm eylem oranında artış bildirilmiştir (14). Yine bir derlemede COVID-19 enfeksiyonu gebelikte hastanede yatış oranlarını artırmakla beraber kötü maternal ve neonatal sonuçlara yol açmadığı saptanmıştır (15). Yüksek gebe hasta sayısına sahip diğer bir derlemede ise COVID-19 enfeksiyonu olan gebelerde tüm nedenlere bağlı neonatal ölüm oranı $\% 0,2-0,3$ olarak belirlenmiş olup COVID-19 enfeksiyonu olmayan gebelerde beklenen neonatal ölüm oranı ile benzerdir (16). Yapılan mevcut çalışmada ise hastanede yatış oranı, preterm doğum oranı gruplar arasında istatistiksel olarak benzer saptanmıştır. Fakat yenidoğan yoğun bakım intiyacı ise COVID-19 enfeksiyonu ile komplike olmayan kont- 
rol grubunda istatistiksel olarak anlamlı daha yüksek oranlar belirlenmiştir. Bu durum derlemeye dahil edilen kontrol grubu içinde fetal hastalık veya distres nedenli doğum kararı alınan gebe sayısının fazla olmasından kaynaklanabilir. Ayrıca yenidoğan PCR taramasında \%2 pozitiflik saptanırken, COVID-19 nedenli yenidoğan ölümü bildirilmemiştir. Sonuç olarak COVID-19 enfeksiyonu ile kötü neonatal sonuçlar arasında ilişki saptanmamıştır.

\section{Sonuç}

Covid-19 enfeksiyonu ile komplike gebe hastalarda, maternal ve neonatal sonuçların kötüleştiğine dair belirgin bulgu saptanmamış olup hasta olmayan gebelerle karşılaştırıldığında benzer maternal ve neonatal sonuçlar belirlendi. Anneden bebeğe vertikal geçiş gösterilmemekle beraber \%2 yenidoğan PCR ile pozitiflik oranı bildirilmiştir. Doğum şeklinin obstetrik endikasyonlara göre belirlenmesi ve asemptomatik olguların yüksekliği nedeni ile hastaneye yatırılan tüm gebelerin Covid-19 açısından taranması önerilmelidir.

\section{Kaynaklar}

1. Ng PC. Infection control for SARS in a tertiary neonatal centre. Arch Dis Child - Fetal Neonatal Ed [Internet]. 2003 Sep 1;88(5):405F - 409.

2. Alfaraj $\mathrm{SH}, \mathrm{Al}$-Tawfiq JA, Memish ZA. Middle East Respiratory Syndrome Coronavirus (MERS-CoV) infection during pregnancy: Report of two cases \&amp; review of the literature. J Microbiol Immunol Infect [Internet]. 2019 Jun;52(3):501-3.

3. Allotey J, Stallings E, Bonet M, Yap M, Chatterjee S, Kew T, et al. Clinical manifestations, risk factors, and maternal and perinatal outcomes of coronavirus disease 2019 in pregnancy: living systematic review and meta-analysis. BMJ [Internet]. 2020;

4. Yanes-Lane M, Winters N, Fregonese F, Bastos M, Perlman-Arrow S, Campbell JR, et al. Proportion of asymptomatic infection among COVID-19 positive persons and their transmission potential: A systematic review and meta-analysis. PLoS One. 2020;

5. Zambrano LD, Ellington S, Strid P, Galang RR, Oduyebo T, Tong VT, et al. Update: Characteristics of Symptomatic Women of Reproductive Age with Laboratory-Confirmed SARS-CoV-2 Infection by Pregnancy Status - United States, January 22October 3, 2020. MMWR Morb Mortal Wkly Rep [Internet]. 2020 Nov 6;69(44):1641-7.

6. Cosma S, Carosso AR, Cusato J, Borella F, Carosso M, Bovetti M, et al. Coronavirus disease 2019 and first-trimester spontaneous abortion: a case-control study of 225 pregnant patients. Am J Obstet Gynecol [Internet]. 2020 Oct 8;

7. Liu W, Wang Q, Zhang Q, Chen L. Coronavirus disease 2019 (COVID-19) during pregnancy: a case series. Preprint. 2020;

8. Simões e Silva AC, Leal CRV. Is SARS-CoV-2 Vertically Transmitted? Front Pediatr [Internet]. 2020 May 15;8.

9. Wong SF, Chow KM, Leung TN, Ng WF, Ng TK, Shek CC, et al. Pregnancy and perinatal outcomes of women with severe acute respiratory syndrome. Am J Obstet Gynecol [Internet]. 2004 Jul;191(1):292-7.

10. Mullins E, Evans D, Viner RM, O'Brien P, Morris E. Coronavirus in pregnancy and delivery: rapid review. Ultrasound in Obstetrics and Gynecology. 2020.
11. Yu N, Li W, Kang Q, Xiong Z, Wang S, Lin X, et al. Clinical features and obstetric and neonatal outcomes of pregnant patients with COVID-19 in Wuhan, China: a retrospective, single-centre, descriptive study. Lancet Infect Dis [Internet]. 2020 May;20(5):559-64.

12. Qiancheng X, Jian S, Lingling P, Lei H, Xiaogan J, Weihua L, et al. Coronavirus disease 2019 in pregnancy. Int J Infect Dis [Internet]. 2020 Jun;95:376-83.

13. Della Gatta AN, Rizzo R, Pilu G, Simonazzi G. Coronavirus disease 2019 during pregnancy: a systematic review of reported cases. Am J Obstet Gynecol [Internet]. 2020 Jul;223(1):36-41.

14. Ashraf MA, Keshavarz $P$, Hosseinpour $P$, Erfani A, Roshanshad A, Pourdast A, et al. Coronavirus disease 2019 (COVID-19): A systematic review of pregnancy and the possibility of vertical transmission. Journal of Reproduction and Infertility. 2020.

15. Salem D, Katranji F, Bakdash T. COVID-19 infection in pregnant women: Review of maternal and fetal outcomes. Int J Gynecol Obstet [Internet]. 2021 Mar 27;152(3):291-8.

16. Mullins E, Hudak ML, Banerjee J, Getzlaff T, Townson J, Barnette $\mathrm{K}$, et al. Pregnancy and neonatal outcomes of COVID-19 - co-reporting of common outcomes from the PAN-COVID and AAP SONPM registry. medRxiv. 2021; 